\title{
An Empirical Research on the Impact of German Refugee Flows on Euro Exchange Rate
}

\author{
Hang Li \\ Shanghai University \\ P.R. China
}

\begin{abstract}
Since 2015, German refugee problem has worsened continuously, attracting worldwide attention. The refugee flows have a certain blow on Germany economy and have caused the euro tumble against China Yuan. In order to analyze the impact of German refugee flows on Euro exchange rate, this paper makes research and gathers vast statistics and data, conducting empirical analysis. The refugee data have been chosen as the primary explanatory variable. Our findings indicate that the increasing refugee number has downward pressure on the euro, which leads to the devaluation of the euro to a certain extent. At the end of the paper, the practical significance of the impact of German refugee flows on euro exchange rate is discussed and some strategic recommendation on how China should learn a lesson from it is also put forward.
\end{abstract}

Keywords-Germany refugee flows; Euro exchange rate; regression analysis; purchasing power parity theory

\section{INTRODUCTION}

Over the years, there are a large number of refugees because of the frequent wars in the Middle East and the African region and the undeveloped economy. Due to the high situation of European economy and the more liberal policy of accepting refugees, most refugees have chosen to seek shelters in European countries. Since 2014, the European refugee crisis has broken out. Germany has become the best choice for refugees because of its loose refugee policy, humanitarianism and great social welfare. Also, from 2015, the euro exchange rate began to fluctuate widely, and the overall trend began to decline. Due to the good development of China and Germany, the euro is very popular in the Chinese foreign exchange market. Therefore, the study of the euro exchange rate has become particularly important.

This paper is theoretically significant because many seniors and scholars in the field of exchange rate research have made a great contribution to the study of the euro exchange rate, but the study of the impact of the refugee flow on the euro exchange rate can be rarely seen. This paper will be a complement to the exchange rate research field. In terms of practical significance, as a very important currency in Chinese foreign exchange market, the fluctuation of euro exchange rate have a significant impact on all aspects, including investment, studying abroad, tourism, currency swap and so on.

\section{LITERATURE REVIEW AND THEORETICAL BASIS}

\section{A. Literature Review on the Influencing Factors of Exchange Rate Fluctuation}

Xiao Ziqiong (2009) pointed out that the main factors affecting the euro exchange rate are economic growth rate, inflation rate and interest rate. She made empirical analysis based on the time sequence using $\mathrm{ARCH}$ and GARCH model [1]. Liu Guangyuan (2011) selected the purchasing power parity model and interest rate parity model as the basic economic model, and made the empirical research on the impact of European debt crisis on the euro-dollar and the euro-RMB exchange rate. The author believes that CPI index and interest rate are the main factors that influence the euro [2]. Yang Changjiang, Zhong Ninghua (2012) argued that purchasing power parity is one of the most important ways to measure equilibrium exchange rate. Compared with the basic equilibrium exchange rate and other methods, the extended purchasing power parity method is more suitable for measuring the equilibrium exchange rate of RMB [3].

Li Xunshi (2012) used the behavioral equilibrium exchange rate model BEER, with the data from the first quarter of 1999 to the first quarter of 2007, and estimated the euro equilibrium real exchange rate and real euro exchange rate misalignment. Results of the cointegration analysis show that the improvement of relative terms of trade will lead to appreciation of equilibrium rate of exchange [4]. Yu Hongze (2015) made use of the factor analysis method and studied the basic factors that influence the euro exchange rate from five aspects, including the economic growth of major member countries in the euro area, the euro zone balance of payments, the euro zone inflation, the European Central Bank monetary policy and the European debt crisis. The conclusion is drawn that the euro zone economic growth and the U.S. dollar index are the most important factors [5].

\section{B. The Main Theory of Exchange Rate Fluctuation}

\section{1) Purchasing Power Parity Theory}

The purchasing power parity theory (PPP) is proposed by British economist Thornton (1802). The theory holds that the currency ratio of two countries depends on commodity purchasing power of two countries' currencies. And the purchasing power is manifested by the price level. Domestic price raise will lead to the devaluation of the domestic currency. The exchange rate is determined by the price level. Purchasing power parity is divided into absolute purchasing power parity and relative purchasing power parity. 
The absolute purchasing power parity formula is shown as Equation 2.1. To facilitate the understanding, this paper uses German (DE) currency $(€)$ and Chinese $(\mathrm{CH})$ currency (¥) as an example:

$$
E_{€ / ¥}=P_{D E} / P_{C H}
$$

$\mathrm{E}_{€ / ¥}$ RepresentsRMB against the euro exchange rate; $\mathrm{P}_{\mathrm{DE}}$ represents German price level; $\mathrm{P}_{\mathrm{CH}}$ represents Chinese price level.

The relative purchasing power parity formula is shown as Equation 2.2:

$$
\left(\mathrm{E}_{€ / ¥, \mathrm{t}}-\mathrm{E}_{€ / ¥, \mathrm{t}-1}\right) / \mathrm{E}_{€ / ¥, \mathrm{t}-1}=\pi_{\mathrm{DE}, \mathrm{t}}-\pi_{\mathrm{CH}, \mathrm{t}}
$$

$E_{€ / ¥, t}$ represents $\mathrm{RMB}$ against the euro exchange rate in the $\mathrm{t}$ period; $\mathrm{E}_{€ / ¥, \mathrm{t}-1}$ represents $\mathrm{RMB}$ against the euro exchange rate in the $\mathrm{t}-1$ period; $\pi_{\mathrm{DE}, \mathrm{t}}$ represents German inflation in the $\mathrm{t}$ period; $\pi_{\mathrm{CH}, \mathrm{t}}$ represents Chinese inflation rate in the $\mathrm{t}$ period; the relative purchasing power parity theory holds that the rate of change of exchange rate is equal to the rate of change of price level.

\section{2) Interest Parity Theory}

British economist Keynes (1932) proposed interest rate parity theory (IRP), which is also known as forward exchange rate decision theory. The theory points out that the interest rate difference between the two countries is equal to the difference between the forward exchange rate $\mathrm{F}$ and the spot exchange rate $\mathrm{S}$. The difference between the forward and the spot is determined by the difference of the interest rate between the two countries. The currency of the country with high interest rate will depreciate, and the currency of the country with low interest will appreciate, which means that interest rate $\mathrm{R}$ is the main factor, affecting exchange rate fluctuation. The formula is shown as Equation 2.3:

$$
\mathrm{R}_{€}=\mathrm{R}_{¥}+\left(\mathrm{E}^{\mathrm{e}}-\mathrm{E}\right) / \mathrm{E}
$$

$\mathrm{R}_{€}$ represents euro interest rate, $\mathrm{R}_{¥}$ represents $\mathrm{RMB}$ interest rate, $\left(\mathrm{E}^{\mathrm{e}}-\mathrm{E}\right) / \mathrm{E}$ represents the appreciation rate of RMB.

\section{GERMAN REFUGEE FLOW AND EURO EXCHANGE RATES}

In recent years, the refugee ship-sinking incidents in Mediterranean have occurred frequently. In April 2015, there were three major ship-sinking incidents in Italy, Libya and Greece, killing more than 20,000 refugees and opening the prelude to the European refugee crisis. Germany has accepted the largest number of refugees in Europe because of its open refugee policy and strong economic strength, hoping to play a leading role in the refugee crisis and to promote the EU common solution. In the first half of 2015, compared with the rest of the EU, Germany accepted about 150,000 refugees, ranking the first among industrial countries. By the end of 2015, Germany had accepted about one million refugees in a new round of refugee flows [6].

As far as the present situation, Germany has had a tremendous impact on the domestic community because of accepting large numbers of refugees. Munich and Cologne has become the largest refugee rallying points, commuter trains are blocked, private homes are forced to rent as refugee shelters, clashes and riots in the refugee camps happen occasionally. In addition, the surge of the refugee number has led the German federal budget for refugees in 2015 to rise from $€ 1$ billion to $€ 7$ billion, with an average expense of about 12,000 to 13,000 euro per year for a refugee. Some Germans are afraid that the refugees will bring about job competition and threaten German social welfare [7].

The problem triggered in all aspects makes investors' confidence in Germany decline. The euro exchange rate fluctuation is the most obvious. From Figure 3.1 and Figure 3.2 , it can be seen that, from 2006 to 2015, the number of refugees is rising, and it began to surge since 2015 . While the euro exchange rate fall from 2015, with large fluctuation.

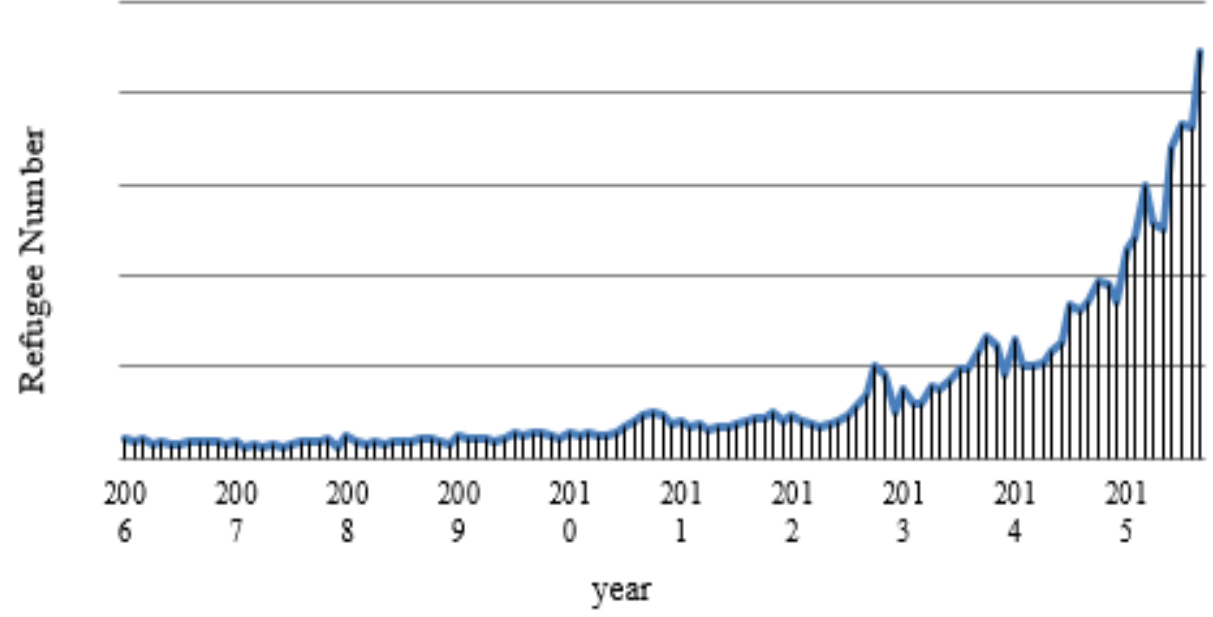

Fig. 1 The chart of refugee number (2006-2015) 


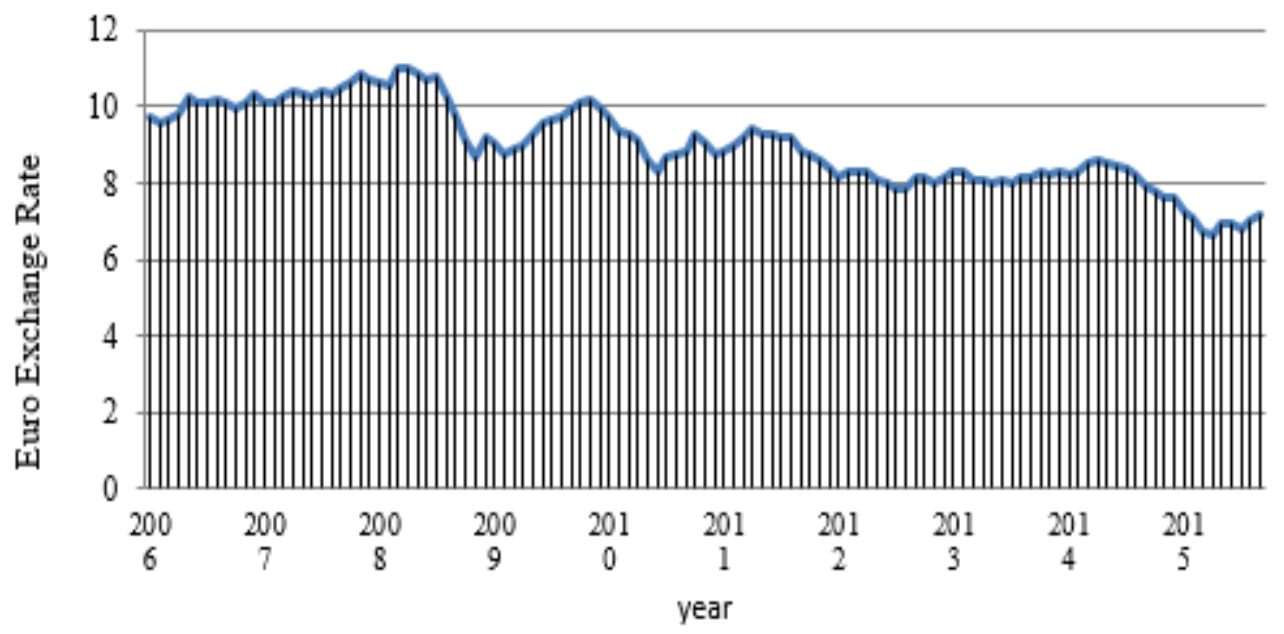

Fig. 2 The chart of euro exchange rate (2006-2015)

\section{EMPIRICAL TEST OF THE IMPACT OF REFUGEE FLOW ON THE EURO EXCHANGE RATE}

\section{A. Research Hypothesis}

The German refugee flow has aroused public concern about the social and economic security of the EU, exacerbating the tensions of the geopolitical situation. The huge public expense on refugees has also made the EU economic market more testable. All of this will make a slump in investor confidence. It is foreseeable that the German refugee flow will have a negative impact on the German economy, and the euro exchange rate will inevitably be affected. It is assumed that there is a negative correlation between the German refugee number and the euro exchange rate $(¥ / €)$.

\section{B. Variable Design and Data Sources}

\section{1) Variable Design}

According to the absolute purchasing power parity, RMB against euro exchange rate can be written as formula 4.1(for clarity, this paper takes the German $(€)$ currency euro $(€)$ and Chinese (CH) currency(¥)for example:

$$
\mathrm{E}_{€ / Y}=\frac{\mathrm{P}_{\mathrm{DE}}}{\mathrm{P}_{\mathrm{CH}}}
$$

The price depends on the supply and demand level of domestic money market. It is shown as formula 4.2:

$$
\mathrm{P}_{\mathrm{DE}}=\frac{\mathrm{M}_{\mathrm{DE}}^{\mathrm{S}}}{\mathrm{L}\left(\mathrm{R}_{\epsilon}, \mathrm{Y}_{\mathrm{DE}}\right)}
$$

$\mathrm{M}^{\mathrm{S}}$ represents the domestic money supply; L represents the domestic real money demand, which is determined by the interest rate $\mathrm{R}$ and the domestic output level $\mathrm{Y}$. If other conditions remain the same, when the money supply $M^{S}$ increases, domestic price increases; when the interest rate $\mathrm{R}$ increases, domestic real money demand decreases, and domestic price increases; when domestic output increases, real money demand increases and domestic price decreases.

According to the formulas 4.1 and 4.2, the relationship between exchange rate and money supply and demand, interest rate and output can be obtained, as shown in Equation 4.3:

$$
\mathrm{E}_{€ / ¥}=\frac{\mathrm{M}_{\mathrm{DE}}^{\mathrm{S}}}{\mathrm{M}_{\mathrm{CH}}^{\mathrm{S}}} * \frac{\mathrm{L}\left(\mathrm{R}_{¥}, \mathrm{Y}_{\mathrm{CH}}\right)}{\mathrm{L}\left(\mathrm{R}_{€}, \mathrm{Y}_{\mathrm{DE}}\right)}
$$

Therefore, in order to explore the impact of refugee numbers on euro exchange rate, this paper selects the following indicators summarized in Table 4.1: 
TABLE I Variable definition and declaration

\begin{tabular}{|c|c|c|c|}
\hline & Variable name & Variable symbol & variable declaration \\
\hline $\begin{array}{l}\text { Explained } \\
\text { variable }\end{array}$ & Euro exchange rate $(¥ / €)$ & EUROEXR & $\begin{array}{l}\text { The amount of RMB that can be converted } \\
\text { by one euro }\end{array}$ \\
\hline $\begin{array}{l}\text { Explanatory } \\
\text { variable }\end{array}$ & $\begin{array}{l}\text { German refugee number } \\
\text { (ln (number of people)) }\end{array}$ & REFUGEE & Take the logarithm \\
\hline \multirow{5}{*}{$\begin{array}{l}\text { Control } \\
\text { variable }\end{array}$} & Sino-Germany inflation rate difference $(\%)$ & IFDIFF & $\begin{array}{l}\text { The difference between Chinese inflation } \\
\text { rate and German inflation rate }\end{array}$ \\
\hline & Sino-Germany interest rate difference $(\%)$ & ITDIFF & $\begin{array}{l}\text { The difference between Chinese loan } \\
\text { interest rate and German loan interest rate }\end{array}$ \\
\hline & Chinese GDP growth of year (\%) & CGDPG & $\left(\mathrm{GDP}_{\mathrm{n}}-\mathrm{GDP}_{\mathrm{n}-1}\right) / \mathrm{GDP}_{\mathrm{n}-1}$ \\
\hline & German GDP growth of year $(\%)$ & GGDPG & $\left(\mathrm{GDP}_{\mathrm{n}}-\mathrm{GDP}_{\mathrm{n}-1}\right) / \mathrm{GDP}_{\mathrm{n}-1}$ \\
\hline & Sino-Germany trade balance (billion) & TB & $\begin{array}{l}\text { The difference between German exports } \\
\text { and imports with China }\end{array}$ \\
\hline
\end{tabular}

\section{2) Data Sources}

Among these seven variables, the euro exchange rate data is from the European Central Bank database; the refugee number data is from the United Nations refugee organization's official database; German loan interest rate data is from the European Central Bank database; German import and export with China and the German GDP as well as German CPI index data are derived from Federal
Statistical Office of Germany; Chinese GDP data is from the People's Bank Of China; Chinese loan interest rate and the Chinese CPI index data are from East Money Net.

The data used in this paper are monthly data from January 2006 to September 2015, including 117 months.

3) Descriptive Statistics

The variable characteristics are summarized in Table 4.2:

TABLE II Descriptive statistics

\begin{tabular}{|c|c|c|c|c|c|}
\hline Variable & Observation & Mean & variance & Minimum & maximum \\
\hline Euro exchange rate (EUROEXR) & 117 & 9.0085 & 1.0867 & 6.6863 & 11.0237 \\
\hline German refugee number (REFUGEE) & 117 & 8.3309 & 0.9346 & 7.0926 & 10.7028 \\
\hline Sino-Germany inflation rate difference (IFDIFF) & 117 & 0.6708 & 0.6834 & -0.913 & 2.741 \\
\hline Sino-Germany interest rate difference (ITDIFF) & 117 & 1.9486 & 0.7140 & 0.12 & 2.97 \\
\hline Chinese GDP growth of year (CGDPG) & 117 & 1.3485 & 5.2158 & -13.8853 & 10.7756 \\
\hline German GDP growth of year (GGDPG) & 117 & 0.2324 & 0.3704 & -2.0727 & 0.9731 \\
\hline Sino-Germany trade balance (TB) & 117 & -13.6380 & 8.2942 & -29.5765 & 5.6201 \\
\hline
\end{tabular}

C. Empirical Process and Analysis

1) PearsonCorrelation Test
The statistical results of correlation test between explained variable (EUROEXR) and explanatory variables are shown in Table 4.3:

TABLE III Pearson correlation test

\begin{tabular}{|c|c|c|c|c|c|c|c|}
\hline & EUROEXR & REFUGEE & IFDIFF & ITDIFF & $\begin{array}{c}\text { CGDP } \\
\text { G }\end{array}$ & GGDPG & TB \\
\hline EUROEXR & 1 & & & & & & \\
\hline REFUGEE & -0.7452 & 1 & & & & & \\
\hline & 0.0000 & & & & & & \\
\hline IFDIFF & 0.1598 & -0.0351 & 1 & & & & \\
\hline & 0.0000 & 0.2069 & & & & & \\
\hline ITDIFF & 0.5337 & 0.4166 & -0.0632 & 1 & & & \\
\hline & 0.0000 & 0.0000 & 0.4986 & & & & \\
\hline CGDPG & 0.0253 & 0.006 & 0.0825 & 0.1451 & 1 & & \\
\hline & 0.0000 & 0.1191 & 0.0000 & 0.0000 & & & \\
\hline GGDPG & 0.1040 & -0.0561 & -0.3924 & -0.0321 & 0.1449 & 1 & \\
\hline & 0.0000 & 0.2928 & 0.0000 & 0.0000 & 0.1961 & & \\
\hline
\end{tabular}




\begin{tabular}{|c|c|c|c|c|c|c|c|}
\hline \multicolumn{7}{|c|}{ Table III, cont. } \\
\hline & & & & & & & \\
\hline TB & 0.5884 & 0.3534 & -0.3518 & 0.6571 & 0.1608 & 0.1749 & 1 \\
\hline & 0.0000 & 0.0001 & 0.0001 & 0.0000 & 0.0832 & 0.0592 & \\
\hline
\end{tabular}

Table 4.3 shows the results of the Pearson correlation test. The results indicate that there is a negative correlation between the euro exchange rate (EUROEXR) and refugee number (REFUGEE), the correlation coefficient is -0.7452 , which is the biggest and means the correlation is significant. EURDEXR and ITDIFF, IFDIFF, CGDPG, GGDPG and German trade balance with China (TB) are 0.1598, 0.5337, $0.0253,0.1040$ and 0.5884 respectively, which indicates that there is a positive correlation between the EUROEXR and these five control variables, and the relationship is significant. But the correlation coefficient between the euro exchange rate (EUROEXR) and Chinese GDP growth rate (CGDPG) is only 0.0253.The relationship is weak.

2) VIF test

TABLE IV Variance expansion factor VIF test

\begin{tabular}{|c|c|c|}
\hline Variable & VIF & $1 /$ VIF \\
\hline ITDIFF & 2.36 & 0.423895 \\
\hline TB & 2.35 & 0.424906 \\
\hline REFUGEE & 1.96 & 0.509077 \\
\hline IFDIFF & 1.42 & 0.704770 \\
\hline CGDPG & 1.26 & 0.791231 \\
\hline GGDPG & 1.10 & 0.908875 \\
\hline Mean VIF & 1.74 & \\
\hline
\end{tabular}

Table 4.4 shows the results of the VIF test. The results indicate that the variance expansion factor of each variable is much less than 10 , and the corresponding tolerance is greater than 0.1 , indicating that there is no multiple co linearity between the explanatory variables.
3) Model Set Up

This paper sets the model as follow:

euroexr $=\beta_{0}+\beta_{1}$ refugee $+\beta_{2}$ indiff $+\beta_{3}$ itdiff +

$\beta_{4}$ cgdpg $+\beta_{5}$ ggdpg $+\beta_{6}$ tb $+\mu$

TABLE V Model estimation results

\begin{tabular}{|c|c|c|}
\hline Variable & Variable name & coefficient( $p$ value) \\
\hline Explained variable & German refugee number (REFUGEE) & $\begin{array}{c}-1.0055^{*} * * \\
(0.000)\end{array}$ \\
\hline \multirow{5}{*}{ Explanatory variable } & Sino-Germany inflation rate difference (IFDIFF) & $\begin{array}{c}0.0525^{*} \\
(0.080)\end{array}$ \\
\hline & Sino-Germany interest rate difference (ITDIFF) & $\begin{array}{c}0.2138 * * \\
(0.045)\end{array}$ \\
\hline & Chinese GDP growth of year (CGDPG) & $\begin{array}{c}0.0192 * \\
(0.052)\end{array}$ \\
\hline & German GDP growth of year (GGDPG) & $\begin{array}{c}0.1524 * \\
(0.074)\end{array}$ \\
\hline & Sino-Germany trade balance (TB) & $\begin{array}{c}0.0301 * * * \\
(0.000) \\
\end{array}$ \\
\hline \multirow{3}{*}{ Other } & Constant term & $\begin{array}{c}16.3258 * * * \\
(0.000)\end{array}$ \\
\hline & Observations & 117 \\
\hline & R-Square & 0.7973 \\
\hline
\end{tabular}


According to the regression results in Table 4.5, the specific form of the model is as follow:

$$
\begin{gathered}
\text { euroexr }=16.3258-1.0055 \text { refugee }+0.0525 \text { ifdiff }+ \\
0.2138 \text { itdiff }+0.0192 \text { cgdpg }+0.1524 \text { ggdpg }+0.0301 \text { tb }
\end{gathered}
$$

It can be seen from Table 4.5 that the correlation coefficient between the euro exchange rate and the refugee number after the addition of the control variable is -1.005 and is significant at the $99 \%$ confidence level, proving that the increase in the number of refugees has a downward pressure on the euro exchange rate. The assumption of this paper has been validated.

In addition, five explanatory variables all have positive impact on the euro exchange rate with corresponding significant level, which is consistent with the previous analysis.

\section{MAIN CONCLUSIONS AND POLICY SUGGESTIONS}

\section{A. Main Conclusions}

Through the results of previous empirical analysis, German refugee number and the euro exchange rate is negative correlated.

From a practical perspective, the German refugee crisis does bring downward pressure on German economic situation. In order to cope with the surging refugees, the German budget has increased sharply. How to resettle the refugees? How to convert refugees into usable employment? How to protect the rights and interests of refugees and so on? All of these need a lot of money support, which undoubtedly gives the German economic development a heavy burden, and the euro exchange rate will inevitably be affected and fluctuate. And then the euro exchange rate fluctuations will have a huge impact on the German economy and the Chinese economy.

From the point of psychological expectation, with exponential growth of refugees in Europe, social and cultural conflicts and the associated terrorist suspects have become the practical problems that Germany and European countries have to face. The surging refugees are encumbrance to German public services. The allegations of criminal cases against refugee suspects are endless. The security of the economic investment environment is difficult to be guaranteed. If things continue this way, the market confidence in the euro currency will be greatly reduced because investors are bound to take refugee problems into account.

\section{B. Policy Suggestions}

First of all, we should improve and perfect the exchange rate mechanism and develop foreign exchange market. It is very important to maintain the basic stability of RMB exchange rate at a relatively balanced and reasonable level. To do that, the foreign exchange market must be more sound and perfect. An active foreign exchange market and complete exchange transactions can make the market participants' expectation more accurate.

Second, we should actively improve the trade strategy to achieve the basic balance of import and export trade. The main objective of foreign exchange management is to achieve the appropriate surplus of balance of payments. China government should give enterprises more autonomy of using foreign currency; try to reduce foreign exchange restrictions and encourage the domestic enterprises to invest in the euro area, ensuring the basic balance of import and export trade. This will promote economic sustainable development.

In addition, China should pay close attention to the trend of the euro and international status, carefully adjusting the currency structure of foreign exchange reserves. In order to cope with fluctuations of the exchange, China should also maintain foreign exchange reserves at a basically stable state.

\section{REFERENCES}

[1] X. Ziqiong, "Euro exchange rate fluctuation trend research based on time series model", 2009, Zhongnan University.(In Chinese)

[2] L. Guangyuan, "Forecast of euro exchange rate under European debt crisis", Journal of Agrotechnical Economics, 2011, 03:83-88.

[3] Y. Changjiang and Z. Ninghua, "Purchasing power parity and RMB equilibrium exchange rate", Journal of Financial Research, 2012, 01:36-50.

[4] L. Xinshi, "Euro equilibrium exchange rate analysis", China Price, 2012, 11:68-71.

[5] Y. Hongze, "Influencing factors analysis of euro exchange rate after European debt crisis", 2015, Jilin University.(In Chinese)

[6] W. Huiping, "German response and policy adjustment in European refugee crisis", Sociological Abstracts, 2016, pp. 50-51.

[7] S. Zhonghao, "How does the German economy respond to refugee flows?”, Economic Information Daily, 2016, 08004. 